The intestines and stomach were found perfectly normal ; wo congertion of the parts nor ulceration of Peyer's glands. In the liver and kidneys, which were enlarged; fatty globules appeared on the cut surface. Upon a careful examination the urine showed an abundance of albumen and an entire absence of urea. A microscopic examination revealed fat globules and casts.

The opinion of the medical gentlemen present was that the patient died of uræmia ; that this was induced by exposure to cold, the dyspncea being caused by the restricted position of the lungs consequent upon the firm and extended adhesion; that this also aided in causing the congestion of the kidneys, and thus hastened the result.

The abnormal condition of the heart was probably congenital, and had but little to do with the symptoms.

\title{
ABSTRACT OF SANITARY REPORTS RECEIVED DURING THE PAST WEEK UNDER THE NATIONAL QUARANTINE ACT. - No. XVII.
}

Office Surgeon-Generad U. S. M. H. S., Washington, November 2, 1878.

New Orleans, LA. - There were 83 new cases of yellow fever and 109 deaths for the week ended yesterday. During the week the Board of Health received information of 288 old cases not previously reported. For the past twenty-four hours there were four new casee and eight deaths. Total cases 13,252, total deaths 3973.

Morgan Citr, La. - During the past week there were eight deaths from yellow fever. Total cases to date 563, deaths 102.

Baton Rougr, LA. - For the week ended yesterday evening there were 75 cases of yellow fever and 16 deaths. Total cases 2415 , deaths 160 .

Mobile, Ala. - During the week ended yesterday evening there were 60 new cases of yellow fever and 10 deaths. Total cases 224, deaths 59.

Decatur, Ari. - There were 10 cases of yellow fever and two deaths for the week ended November 1st. Total cases 188, deaths, 42.

BAY St. Lours, Mrss. - Total cases of yellow fever to yesterday evening 535, deaths 78. Only an occasional case occurring now, and the local health authority considers the epidemic at an end.

Port Grbson, Mrss. - There were about ten deaths in the country near Port Gibson during the past week; none in Port Gibson, where the epidemic is considered at an end.

Pass Christian, Mrss. - During the week ended yesterday evening there were 19 cases of yellow fever and no deaths. Two deaths from yellow fever occurred in the week ended October 25th, which were not reported in that week. Total cases to date 189, deaths 20.

Grand Junction, Tens. - To October 26th there were 174 cases of yellow fever and 74. deaths.

Milan, Tenn. - For the two weeks ended yesterday evening there were 12 cases of yellow fever and six deaths. Total cases 15, deaths 9.

Memphis, Tens. - Daring the week ended October 31 st there were 22 deaths from yellow fever. Total deaths 2964. The Board of Health announced officially, October 28th, that absentees could return with safety.

Mason, Tens. - The first case of yellow fever - a refugee-occurred Angust 29th, the first case among inhabitants October 4 th, since which time to yesterday evening there have been 60 cases and 24 deaths.

Cantramooga, Tens. - During the week ended yesterday evening there were 28 new casses of yellow fever and 12 deaths. Total cases 433 , deaths 127.

Meridian, Miss. - Over 400 cases of yellow fever are reported to have occurred to date: Total deaths, 80.

Gallipours, Orio. - During the week ended October 30th one new case of yellow fever occurred and two deaths.

No cases of yellow fever or deaths in Louisville and Key West during the past week.

Havana, CUBA. - Twenty-three deaths from yellow fever and nine from small-pox fot the week ended October 26th.

RIO DE JANEIRO. - One death from yellow fever and 11 deaths from "pernicious fever" for the week ended September 28th. In the same week there were 1495 deaths from all 
causes, of which 139 were from small-pox. Since May 1, 1878, there have been 1233 deaths from small-pox.

EUROPE. - In 149 cities and towns of the German Empire, having an aggregate population of $7,429,793$, there were 5755 births and 3512 deaths for the week ended October 5th, being an annual mortality rate of 24.6 per 1000 of the population. The lowest death rate, 11.2, was in Kiel ; the highest, 42.2, was in Augsburg. The denths include 108 from scarlet fever and 147 from diphtheria and croup. None from small-pox.

JoHN M. WOODWORTh,

Surgeon-General U. S. Marine Hospital Service.

COMPARATIVE MORTALITY-RATES.

\begin{tabular}{|c|c|c|c|c|c|}
\hline & Estimated Pop- & Deaths during & Annual & eath-Rates per & 1000 living. \\
\hline & 1878 . & $\begin{array}{l}\text { weex enaing } \\
\text { 0ct. 26, } 1878 .\end{array}$ & $\begin{array}{l}\text { For the } \\
\text { Week. }\end{array}$ & $\begin{array}{c}\text { For the Year } \\
187 \overline{7} .\end{array}$ & $\begin{array}{l}\text { Mean for ten } \\
\text { Years, } 68-77 .\end{array}$ \\
\hline New York. & $1,093,171$ & 448 & 21.31 & 23.42 & 28.71 \\
\hline Philadelphia. & 876,118 & 256 & 15.19 & 18.80 & 21.54 \\
\hline Brooklyn. & 549,438 & 207 & 19.59 & 21.51 & 25.50 \\
\hline Chicago. & 460.000 & 143 & 16.17 & 17.83 & 22.39 \\
\hline Boston. & 375,476 & 144 & 19.94 & 20.10 & 24.34 \\
\hline Providence. & 100,000 & 36 & 18.72 & 18.81 & 19.20 \\
\hline Lowell. & 55,798 & 12 & 11.18 & 19.09 & 22.50 \\
\hline Worcester. & 54,937 & 13 & 12.31 & 20.06 & 22.30 \\
\hline Cambridge. & 53,547 & 18 & 17.47 & 18.69 & 20.83 \\
\hline Fall River. & 53,207 & 19 & 18.57 & 21.35 & 24.96 \\
\hline Lynn. & 35,528 & 13 & 19.03 & 20.42 & 19.67 \\
\hline Springfield. & 33,981 & 15 & 22.97 & 16.02 & 19.77 \\
\hline Salem. & 27,140 & 9 & 17.24 & 20.38 & 21.15 \\
\hline
\end{tabular}

THe graduating exercises of the Medical Department at Dartmouth took place Tuesday evening, October 29th.

Delegates from State Medical Society : T. J. W. Pray, M. D., E. L. Carr, M. D. ; Delegates from Vermont Medical Society : Henry Janes, M. D., L. C. Butler, M. D. ; Committee: F. J. Small, H. M. French, W. F. Swasey.

Graduates, with titles of Theses: Fred Eugene Aldrich, N. Y., Prolapsus Uteri ; John Fairfield Boothby, D. D. S., Me., Rheumatism ; Edward Plinny Brewer, Conn., Sarcourata ; Edward Josiah Brown, A. B., Vt., Opium and Cathartics; Frederick Chesley Clark, Me., Sick Headache ; Albion Edwin Cobb, Me., Right Use of Medicines; Willie Hudson Foster, Mass., Erysipelas ; Henry Minot French, A. B., N, H., Variola ; Joseph Warren Gordon, N. H., Abscess ; Frank Eugene Henderson, Vt., Rupture o Perinæum; Edw. Bigelow Hitchcock, D. M. D., Mass., The Teeth, etc.; Edward Gilman Inlay, N. Y., Luxations of Humerus; Edw. Avery Isbell, B. S., Ohio; Edwin Porter Linfield, Mass., Vaccination; Geo. Franklin Munsey, N. H., Repair of Fractures; Edwin Osgood Pearson, B. S., N. H. (Valedictorian), General Paresis; George Lowis Perry, Vt., Acute Peritonitis; Frederic Joseph Small, Me., Diphtheria ; Wm. T. Smith, A. M., N. H. (Reader), Science and Art of Medicine; Silas Appleton Stephens, Me., Trismus Nascentium; William Franklin Swasey, Vt., Acute Intlammation; George Seeley Thompson, N. Y., Dysentery.

Books and Pamphlets Received. - Harvey and his Discovery. By J. M. DaCosta, M. D., Professor of the Practice of Medicine at the Jefferson Medical College. Philadelphia : J. B. Lippincott \& Co. 1879. (From A. Williams \& Co.) 